\title{
Epidemiologi ved systemisk lupus erythematosus (SLE)
}

\author{
Inge-Margrethe Gilboe \\ Revmatologisk avdeling, Rikshospitalet, 0027 Oslo
}

\begin{abstract}
SAMMENDRAG
Det er utført få epidemiologiske studier av SLE i Norge. De studier som er utført viser liknende hyppighet og forekomst av SLE i Norge som i de øvrige nordiske land og forekomst av mild sykdom med en lav andel av alvorlig indre organ manifestasjoner. Insidens og prevalens er kartlagt i Nord-Norge visende en lavere insidens enn i de øvrige nordiske land, mens prevalensen er sammenliknbar. Tall fra Sverige tyder på stabil insidens, men økende prevalens, forenelig med økt overlevelse. Norske og nordiske studier viser høy kvinneandel og sammenliknbar alder ved diagnose. Studiene tyder på en høyere alder ved diagnose i Skandinavia enn i USA og England. Ut fra de nordiske studier er overlevelsen ved SLE god, selv om den er lavere enn i den generelle befolkningen. Overlevelse i de nordiske og europeiske land er sammenliknbare. Selv om overlevelsen ved SLE er betydelig bedret over tid utgjorde aktiv SLE og infeksjoner $50 \%$ av dødsårsakene i den danske mortalitetsstudien. Aterosklerotisk hjerte-karsykdom var en hyppig dødsårsak i alle studiene. Kardiovaskulær sykdom som hovedårsak til død ved SLE er påvist i den store internasjonale studien hvor pasienter fra Island og Sverige deltok og i andre europeiske og internasjonale studier. Betydelig økt risiko for hjerteinfarkt hos unge SLE-kvinner i Sverige er også påvist tidligere i internasjonale studier og styrker teorien om at SLE per ce er en selvstendig risikofaktor for aterosklerose. Det er ønskelig med flere epidemiologiske studier av SLE i Norge.
\end{abstract}

Gilboe I-M. The epidemiology of systemic lupus erythematosis (SLE). Nor J Epidemiol 2008; 18 (1): 31-36.

\section{ENGLISH SUMMARY}

There has been few studies on the epidemiology of SLE in Norway. The studies that have been conducted show similar frequency and occurence of SLE in Norway in comparison to the other Nordic countries, and mainly occurence of mild disease with only a low proportion suffering severe internal organ involvement. Studies on incidence and prevalence in the northern part of Norway show a lower incidence than in other Nordic countries, but a similar prevalence. Swedish studies has implied a stable incidence and increasing prevalence, correlating with prolonged survival. Studies from Norway and the Nordic countries show a high female predominance and comparable ages at time of diagnosis. The studies imply a later age of diagnosis in Scandinavia than in the USA and the UK. The Nordic studies show that survival from SLE is good, however lower than in the general population. Survival in the Nordic and European countries is comparable. Even if survival of SLE has been greatly improved, the Danish study on mortality showed that $50 \%$ of deaths are caused by infections and active disease. Artheriosclerotic cardiovascular disease is also found to be a frequent cause of death in all the studies. Cardiovascular disease was found to be the main cause of death in SLE in a big international study including Finnish and Swedish patients, and also in other European and international studies. Increased risk of myocardial infarction among young women with SLE in Sweden as well as in international studies indicates that SLE is in itself a risk factor for artheriosclerosis. It would be desirable with more studies on the epidemiology of SLE in Norway.

\section{DEFINISJON}

Systemisk lupus erythematosus (SLE) er en systemisk bindevevssykdom. Den er prototypen på autoimmun sykdom, med dannelse av en rekke autoantistoffer på grunn av tap av immunologisk toleranse ovenfor eget vev. Sykdommen affiserer to eller flere organsystemer og er kronisk. Alvorlighetsgraden er avhengig av hvilke organer som affiseres og aktiviteten i sykdommen på diagnosetidspunktet og ved senere sykdomsoppbluss. Det karakteriske kliniske bilde er preget av kronisk progressiv eller intermitterende inflammasjon $\mathrm{i}$ organ som fører til redusert livskvalitet, kronisk organ- skade og økt mortalitet (1-3). Årsaksforholdene er ufullstendig kartlagt.

\section{HISTORIKK}

Begrepet "lupus" (Ulv) ble allerede brukt i middelalderen for å beskrive hudlesjoner, spesielt dype lesjoner i ansiktet og på beina. Lupus beskrev spesielt dyptgående ulcerasjoner, som kunne se ut som bitt av ulv. Denne assosiasjonen forble uendret frem til 16 . århundre.

Hudlesjonene ble første gang publisert av den franske legen Pierre Cazenave i 1833, som beskrev 
forandringene hos sin mentor Theodore Biett under navnet "erythema centrifugum". Navnet endret han senere til "lupus erythemateux".

Ferdinand von Hebra beskrev i 1845 det karakteristiske sommerfuglutslettet ved sykdommen og publiserte illustrasjoner av det. Kaposi var den som fikk mistanke om sykdommens farlige systemiske natur. Han beskrev dette og de karakteriske diskoide forandringer i huden på 1870-tallet. På begynnelsen av 1900-tallet beskrev flere forfattere, men først og fremst Osler i Baltimore og Jadasohn i Wien sykdommens disseminerte form og kliniske manifestasjoner som gjorde det mulig å skille SLE fra andre tilstander.

En kartlegging av de histopatologiske forandringer ved sykdommen begynte med arbeidet til Liebman og Sachs i 1924, som beskrev de karakteriske verrukøse forandringer på hjerteklaffene, mens Bahr beskrev wire loop forandringene i nyrene 10 år senere.

Påvisning av falsk positiv syfilis test ved SLE er det eldste immunologiske funnet, men det store serologiske gjennombruddet kom i 1948 da Hargraves og kollegaene beskrev LE-cellen i blod og benmarg. Kort tid senere påviste man at faktoren som induserte LEcellen var et gammaglobulin - et antistoff - som var rettet mot elementer i cellekjernen og var positiv i 9598\% ved SLE. Påvisningen av LE-cellefenomenet satte $\mathrm{i}$ gang en intens forskning for andre serologiske forandringer og etter kort tid fulgte oppdagelsen av antistoffer rettet mot DNA og mot ekstraherbare nukleære antigener. Neonatal lupus, som er en tilstand forårsaket av passasje av anti-SSA gjennom placenta til fosteret ble første gang beskrevet i 1954 og subakutt kutan LE karakterisert ved annulært utslett og uttalt solømfintlighet i 1979.

Enkelte SLE-pasienter har en uvanlig koagulasjonsforstyrrelse, kalt lupus antikoagulant. I 1957 fant Laurel at lupus antikoagulant var assosiert med positiv test for syfilis, spontanabort og til trombosedannelse og ikke blødning som tidligere antatt. Kardiolipinantistoff ble påvist senere og i 1986 ble antifosfolipidsyndromet definert.

\section{ARV}

I den senere tid har bruk av dyremodeller (musemodeller) og kartlegging av genetisk disposisjon for sykdommen vært viktig for å forstå sykdommens patogenense. Musemodellen har bl.a. gitt innsyn $i$ hvordan autoantistoff dannes, mekanismer for immunologisk toleranse, utvikling av glomerulonefritt, kjønnshormoners påvirkning av sykdomsaktiviteten og effekt av behandling. Gjennom de siste 30 år er opphoping av SLE i familier påvist og økt forekomst av SLE i monozygote tvillinger versus i heterozygote tvillinger beskrevet. Videre er de 3 "hovedgener" som koder for SLE og deres lokalisasjon på kromosomene kartlagt. Betydningen av påvisning av økt programmert celledød (apoptose) av lymfocyttene og forsinket fjernelse av apoptotisk cellemateriale har gitt oss inn- sikt i hvordan tap av immunologisk toleranse og autoimmunitet kan oppstå.

\section{KLASSIFIKASJON OG DIAGNOSE}

SLE kan være vanskelig å skille fra andre sykdommer, spesielt fra andre systemiske bindevevssykdommer på grunn av overlappende symptomer, kliniske funn og autoantistoffer.

Mangel på diagnostiske kriterier og spesifikke tester for SLE gjør SLE til en klinisk diagnose, basert på multiorgansymptomer og funn, patologiske laboratorietester og immunologiske funn. Av immunologiske tester er ANA-test hyppigst positiv. Positiv ANA sees imidlertid også hos friske, ved andre autoimmune tilstander, ved infeksjonstilstander og ved malignitet. Positiv ANA sammen med mer spesifikke markører for SLE slik som ds-DNA, anti-Sm, ribosomalt P og andre ENA-antistoff styrker SLE-diagnosen. Desto flere autoantistoff desto sikrere SLE-diagnose er en gammel regel.

I den hensikt å kunne klassifisere SLE-pasienter til studier og skille en SLE-pasient fra en pasient med annen systemisk bindevevssykdom publiserte American College of Rheumatology (ACR), tidligere American Rheumatism Association (ARA) de preliminære klassifikasjonskriterier i 1971 (4). Kriteriene ble revidert i 1982. I den reviderte versjon ble 11 manifestasjoner/laboratorietester valgt, inkludert ANA-test, anti ds-DNA og anti-Smith (5). I 1997 ble kriteriene oppdatert, idet positiv LE-celle ble erstattet med antifosfolipid antistoff (6). For å tilfredsstille klassifikasjonskriteriene må en pasient ha 4 eller flere ACRkriterier enten på samme tid eller over tid. Kriteriene av 1971 hadde $88 \%$ sensitivitet og $91 \%$ spesifisitet og kriteriene av 1982 96\% sensitivitet og spesifisitet når de ble anvendt på en gruppe av 245 SLE-pasienter og en kontrollgruppe bestående av 234 pasienter med rheumatoid athritt og 217 andre (7).

I den norske studien til Gilboe et al. (8) ble 76 SLEpasienter og 270 pasienter med andre systemiske bindevevssykdommer klassifisert etter 1982 reviderte kriterier (5). Studien viste en lav sensitivitet på 72\%, men en tilfredsstillende spesifisitet på 91\%. Årsaken til den lave sensitiviteten ble vurdert til å ha sammenheng med studiens retrospektive design. Studien klassifiserte også pasientene etter 1997 oppdaterte kriterier (6) og fant en høyere sensitivitet, men noe lavere spesifisitet.

I de svenske studiene fra Lund fant Nived et al. (9) og Stahl-Hallengren et al. (10) en tilfredsstillende sensitivitet ved bruk av både de preliminære og 1982 reviderte kriterier på sine SLE-kohorter fra henholdsvis 1981-82 og 1987-1991.

Det er viktig å huske på at kriteriene forst og fremst ble laget til forskningsformål og ikke til diagnostisk formål for den enkelte pasient. Det kan gå mange år før en SLE-pasient tilfredsstiller klassifikasjonskriteriene. 
Tabell 1. Insidens og prevalens av SLE i nordiske studier.

\begin{tabular}{llcc}
\hline Studie & Land & Insidens & Prevalens \\
\hline Nossent (2001) (11) & Norge & 2,7 & 44,9 \\
Nived et al. (1981-82) (9) & Sverige & 4,8 & 39 \\
Jonsson et al. (1981-1986) (12) & Sverige & 4,0 & NA \\
Stahl-Hallengren et al. (1987-1991) (10) & Sverige & 4,8 & 68 \\
Voss et et al. (1998) (13) & Danmark & 3,6 & 21,7 \\
Helve et al. (1976-1978) (14) & Finland & NA & 28 \\
Gudmundsson et al. (1975-1984) (14) & Island & 3,3 & 35,9 \\
\hline
\end{tabular}

\section{INSIDENS OG PREVALENS}

Insidens (antall nye tilfeller av SLE per år og per 100.000) og prevalens (forekomst av SLE på et gitt tidspunkt per 100.000) varierer fra en verdensdel til en annen og fra land til land. Både insidens og prevalens er assosiert til rase og andre faktorer som infeksjoner, ultrafiolett bestråling og hormoner. Vi regner med at over fem millioner mennesker i verden har SLE.

I Norge fant Nossent (11) en insidens på 2,7 nye tilfeller per år og en prevalens på 44,9 per $100.000 \mathrm{i}$ Nord-Norge. Det tilsvarer i overkant av 100 nye tilfeller SLE per år og totalt ca. 2250 pasienter i Norge. Insidens- og prevalensundersøkelser fra andre deler av Norge er dessverre ikke utført.

De norske tallene er sammenliknbare med de fra Sverige, hvor det i Lund er utført epidemiologiske studier i 3 perioder, 1981 til 1982 (9), 1981 til 1986 (12) og 1987 til 1991 (11) (Tabell 1). Tallene tyder på at insidensen av SLE i Sverige fra 1981 til 1991 har vært stabil, mens prevalensen har vært stigende. Stigende prevalens kan ha sammenheng med bedre behandling av tilstanden og dermed bedre prognose og høyere levealder. Det er også utført insidens- og prevalensstudier også i Danmark (13), Finland (14) og Island (15) (Tabell 1). Som det fremgår av tabellen fant man en lavere prevalens i Danmark og Finland enn i øvrige nordiske land. Den lave prevalens i Finland kan ha sammenheng med at undersøkelsen fant sted på et tidlig tidspunkt (1970-tallet), mens den lave prevalens i Danmark med studiens retrospektive design. Norske og nordiske studier som nesten bare består av kaukasiere har lavere insidens enn populasjonsstudier av Caribere, asiatere og Hispanere og spesielt Afroamerikanere. Afroamerikanske kvinner har fått påvist 3-4 ganger høyere insidens enn kaukasisike kvinner (16).

\section{KJØNNSDISTRIBUSJON OG ALDER VED DIAGNOSE}

De fleste studier viser at SLE er langt vanligere hos kvinner enn hos menn, selv om ratio varierer noe fra studie til studie. I fertil alder kan SLE være opptil 12 ganger hyppigere hos kvinner enn menn (16). Dette skyldes sannsynlig østrogenpåvirkning som stimulerer lymfocytter. Det ble påvist en høy kvinneandel i de norske studier $(8,11)$ (henholdsvis 90 og 87\%) og likeledes i andre nordiske studier $(9,10,12-15)$.
Tabell 2. Alder ved diagnose av SLE i nordiske studier.

\begin{tabular}{lll}
\hline Studie & Land & \multicolumn{1}{c}{ Alder } \\
\hline Gilboe (1999) (8) & Norge & 36 (mean) \\
Nossent (2001) (11) & Norge & 39,8 (median) \\
Voss et et al. (1998) (13) & Danmark & 37,3 (mean) \\
Nived et al. (1985) (9) & Sverige & 39 (mean) \\
Jonsson et al. (1990) (12) & Sverige & $55-64$ \\
Stahl-Hallengren et al. (2000) (10) & Sverige & 47 (median) \\
Gudmundsson et al. (1990) (15) & Island & 46,6 (mean) \\
\hline
\end{tabular}

Sykdomsbilde ved sykdomsdebut kan være assosiert til kjønn. Fra John Hopkins' SLE-kohort beskrives høyere sykdomsaktivitet og et mer alvorlig sykdomsbilde hos menn enn hos kvinner, med økt forekomst av trombosedannelse, epilepsi og hemolyttisk anemi (16). I studien til Nived et al. (9) ble det funnet økt andel indre organmanifestasjoner hos menn sammenliknet med kvinner, men dette er ikke er sett på i norske studier.

SLE kan oppstå i alle aldre, men alder ved sykdomsdebut og ved diagnose varierer dramatisk mellom raser og fra land til land. Studier viser at kaukasiere er eldre ved diagnose enn Afroamerikanere, AfroCaribere, asiatere og Hispanere (16).

I de 2 studiene som er utført i Norge $(8,11)$ er henholdsvis mean og median alder ved diagnose 36 (11-78) og 39,8 år (Tabell 2). Alder ved diagnose i de øvrige nordiske studier viser variasjon fra 37,3 til 5564 år $(9,10,12-15)$. Studiene tyder i retning av en høyere alder ved diagnose i Skandinavia enn i USA og England (16). Det er imidlertid interessant å registre at alder ved diagnose i Rochester, Minnesota, som stort sett bare består av kaukasiere, kan sammenliknes med den i Skandinavia (17). Høyere alder ved diagnose assosieres til mildere sykdomsbilder.

\section{MORTALITET VEd SLE}

Alvorlighetsgraden ved SLE er avhengig av hvilke organsystemer som affiseres og grad av sykdomsaktivitet over tid. Mortalitet er spesielt assosiert til den alvorlige formen av sykdommen, der vitale organ er affisert.

Mortaliteten ved SLE har bedret seg betydelig gjennom siste 50 år. Eksempelvis overlevde kun $50 \%$ av 
pasientene 5 års sykdom i 1950, mens $90 \%$ overlever 5 år og 80\% 10 år sykdom i dag. Økt overlevelse skyldes både bedret behandlingstilbud, inklusive dialyse og nyretransplantasjon, raskere diagnostisering av sykdommen og diagnostisering av mildere tilfeller.

Selv om overlevelse ved SLE er betydelig forbedret er mortalitet 3-4 ganger økt sammenliknet med den i den generelle befolkning (16).

Prognose ved SLE er knyttet opp til prediktive variabler for sykdommen. Av stor betydning for prognose og mortalitet er både demografiske variabler som rase, kjønn, sosioøkonomiske faktorer og sykdomsvariabler som sykdomsaktivitet, indre organaffeksjon og kronisk organskade.

Internasjonale studier har vist at kaukasiere har den langt beste prognose ved SLE og mortaliteten er 2-3 ganger lavere enn for Afroamerikanere (18), og også lavere enn for Afro-Caribere, Hispanere og asiatere (19). Menn har i enkelte studier dårligere prognose enn kvinner, men ikke i alle. Høy sykdomsaktivitet på diagnosetidspunktet har vært prediktor for mortalitet $\mathrm{i}$ andre studier, likeledes høy alder ved diagnose (20). Affeksjon av vitale organ som nyre med høyt blodtrykk, redusert nyrefunksjon og proteinuri, sentralnervesystemet og i enkelte studier også hjerte/lunge og tidlig og høy kronisk organskade er også assosiert med høy mortalitet (3).

Død ved SLE inntrer både tidlig i sykdomsfasen og etter mange års sykdom. Tidlig død skyldes oftest aktiv SLE per ce spesielt hos de med alvorlig sykdom (nyre eller CNS engasjement) og høy sykdomsaktivitet. Videre kan livstruende infeksjon komplisere sykdomsbildet og er i 30-50\% årsak til død $(21,22)$. Død som inntrer senere i sykdomsbilde er ofte er et resultat av mangeårig sykdom og komplikasjoner til sykdommen og behandlingen. Akselerert aterosklerose og hjerte-karsykdom er assosiert til bruk av kortikosteroider og er en hyppig årsak til sen død ved SLE. Risiko for hjerteinfarkt er funnet å være økt med 52 ganger hos unge SLE-kvinner (23) og det er funnet økt risiko for både hjerteinfarkt og slag etter å ha kontrollert for de tradisjonelle risikofaktorer for aterosklerose (24). Fenomenet "Bimodal pattern", som beskrev årsakene til tidlig og sen død ved SLE allerede i 1976 (25) er senere beskrevet i studiene til Abu-Sharka et al. (21) og Cervera et al. (22).

Det finne bare to norske studier som har studert problemstillingen SLE og mortalitet. Begge er utgående fra Nord-Norge og beskriver henholdsvis overlevelse og prediktorer for mortalitet. I studien fra 2001 (11), som først og fremst beskriver prevalens og insidens av SLE i et arktisk område, estimeres 10 åroverlevelse til $75 \%$.

Becker-Merok et al. (26) studerte utviklingen av organskade hos 158 SLE-pasienter over en 12 års periode og relaterte organskade til død og sykdomsaktivitet. Studien viste at mer enn $50 \%$ av pasientene utviklet skade første 10 år, alvorlig skade hos $25 \%$. Risiko for død ble funnet å være vedvarende sykdoms- aktivitet over tid og debut av sykdommen etter 40 års alder og ikke organskade.

Den mest omfattende nordiske studien om SLE og mortalitet er studien til Jacobsen et al. fra 1999 (27) som studerte overlevelse og død hos 513 danske pasienter ved SLE. Dette er en retrospektiv multisenter oppfølgingsstudie hvor 122 av de 513 SLE-pasientene døde under oppfølging. Med en 2,1\% mortalitetsrate per år i den yngste aldersgruppen til 8,1\% i den eldste, overlevde $91 \%, 76 \%, 64 \%$ og $53 \%$ henholdsvis 5,10 , 15 og 20 års sykdomsvarighet (Tabell 3). Mortalitet var økt 4,6 ganger i forhold til den generelle danske befolkning på det tidspunkt. Videre døde flere menn enn kvinner, og de som var 50 år eller mer ved sykdomsdebut.

Årsakene til død i studien fremgår av Tabell 4. SLE per ce var en hyppig dødsårsak i form av alvorlig aktiv multiorgansykdom med hyppigst affeksjon av nyrer og CNS (27). Aktiv SLE som dødsårsak var assosiert med kort sykdomsvarighet ( $<5$ år). Alvorlig organsvikt utviklet seg hyppigst i nyrene (12 av 14). Fatale infeksjoner var hyppig dødsårsak, spesielt hos de med sykdomsdebut $\mathrm{i}$ ung alder og med 5-10 år sykdomsvarighet. SLE og fatale infeksjoner utgjorde $50 \%$ av dødsårsakene. Aterosklerotisk hjerte-kar var også hyppig og ble påvist 2,5 ganger hyppigere hos de med 5-10 år sykdomsvarighet eller lenger.

Halberg et al. (28) studerte også overlevelse og årsak til død i en dansk kohort bestående av 173 SLEpasienter som ble fulgt over 13,9 år i 1991. Begge studiene $(27,28)$ viste sammenliknbar overlevelse og årsaker til død (Tabell 1 og 2).

En stor mengde SLE-studier har utgått fra Sverige. Jonsson et al. (12) studerte i 1989 "outcome" ved SLE over 6 år i en definert populasjon og fant at 5-åroverlevelse i den prospektive gruppen var 95\% (Tabell 3). Videre var sykdomsvarighet og behandling med kortikosteroider hovedårsak til morbiditet og mortalitet i form av infeksjoner og hjerteinfarkt. Infarkt var 9 ganger økt i forhold til den svenske befolkningen.

Stahl-Hallengren et al. (10) studerte insidens av nye SLE-pasienter fra 1987 til 1991 og sammenliknet demografiske og sykdomsvariabler, inklusive overlevelsesrater og mortalitet hos dem med pasienter diagnostisert i perioden 1981-1987. Kalkulert 5 år- og 10 åroverlevelse var henholdsvis 93 og 83\% (Tabell 3). 5 år-overlevelse var ikke redusert sammenliknet med en alders- og kjønnsmatchet kontrollgruppe fra samme område, mens 10 år-overlevelse var lett redusert. Utbredelse av organskade var lik i de 2 kohortene og var høyest hos de som døde. Hele 13 (76\%) døde av komplikasjoner til aterosklerose, hvorav 11 av hjerteinfarkt og hjertesvikt og 2 av cerebralt insult. 4 døde av aktiv SLE-sykdom (Tabell 4).

Også i den omfattende svenske studien til Bjørådal et al. (29) var kardiovaskulær sykdom hovedårsak til død. I studien ble alle SLE-pasienter fra 1964 til 1995 identifisert gjennom et sykehusregister, i alt 4737 pasienter, hvorav 2314 var døde. Standardisert mortali- 
Tabell 3. Overlevelse ved SLE i nordiske studier.

\begin{tabular}{llcccc}
\hline & & \multicolumn{4}{c}{ Overlevelse (\%) } \\
\cline { 3 - 5 } Studie & Land & 5 år & 10 år & 15 år & 20 år \\
\hline Nossent $\mathrm{n}=83(11)$ & Norge & & 75 & & \\
Jacobsen et al. $\mathrm{n}=513(27)$ & Danmark & 91 & 76 & 64 & 53 \\
Halberg et al. $\mathrm{n}=173(28)$ & Danmark & & 80 & 65 & 48 \\
Stahl-Hallengren et al. $\mathrm{n}=86(10)$ & Sverige & 93 & 83 & & \\
Jonsson et al. $\mathrm{n}=86(11)$ & Sverige & 97 & & & \\
Grippenberg et al. $\mathrm{n}=66(31)$ & Finland & & 91 & & \\
Gudmundsson et al. $\mathrm{n}=76(15)$ & Island & 84 & 78 & & \\
\hline
\end{tabular}

Tabell 4. Viktigste dødsårsak ved SLE i nordiske studier.

\begin{tabular}{lcccccc}
\hline Studie & $\begin{array}{c}\text { SLE, } \\
\text { aktiv }\end{array}$ & $\begin{array}{c}\text { SLE, } \\
\text { organsvikt }\end{array}$ & Infeksjon & Malign & $\begin{array}{c}\text { Cerebrovask/ } \\
\text { cardiovask }\end{array}$ & $\begin{array}{c}\text { Andre, } \\
\text { ukjent }\end{array}$ \\
\hline Jacobsen et al. (27), døde $\mathrm{n}=122$ & 19 & 16 & 25 & 9 & 30 & 16 \\
Halberg et al. (28), døde $\mathrm{n}=56$ & & 12 & 12 & & 11 & \\
Stahl-Hallengren et al. (10), døde $\mathrm{n}=17$ & 4 & & & & 13 & 3 \\
Gudmundsson et al. (15), døde $\mathrm{n}=17$ & 2 & & 1 & 6 & 5 & 3 \\
\hline
\end{tabular}

tetsrate med den svenske populasjon som referanse var gjennomsnittlig 3,78 og kardivaskulær sykdom var hovedårsaken til død. Unge pasienter (20-39 år) hadde 16 ganger økt risiko for død på grunn av hjertesykdom. De fant at selv om mortalitet ved SLE hadde falt $i$ løpet av perioden hadde ikke andelen av hjertekarsykdom falt.

I den svenske studien til Nived et al. (30) vektlegges den høye prediktive verdien av kronisk organskade etter 5 års sykdomsvarighet. Organskadeindeks på 2 eller større var assosiert med relativ risiko for $\mathrm{d} ø \mathrm{~d}$ på 3,4 og en prediktiv verdi på $38 \%$ for død. Motsatt var organskade $=0$ etter 5 års sykdomsvarighet assosiert med god prognose og en prediktiv verdi på $97 \%$ for overlevelse.

Det finnes 2 eldre og små studier av SLE fra Fin- land $(14,31)$ hvor overlevelse og mortalitet studeres. Grippenberg et al. (31) finner i 199110 års overlevelse på 91\% i en kohort på 66 pasienter (Tabell 3). Aktiv lupus nefritt, kardiovaskulær sykdom og infeksjoner var de hyppigste dødsårsaker i perioden 1972 til 1978.

I en studie fra Island fra 1990 beskriver Gudmundsson et al. (15) SLE fra 1975 til 1984. De identifiserte 76 nye pasienter. 17 pasienter døde under oppfølging, mens det forventete antall døde ut i fra den generelle befolkningen var 5 . Henholdsvis $84 \%$ og $78 \%$ overlevde 5 og 10 års sykdomsvarighet (Tabell 3). En høy andel døde av malign lidelse og kardiovaskulær lidelse (Tabell 4).

De fleste studier viser således $90 \%$ overlevelse etter 5 år og 80\% etter 10 år og hovedårsak til tidlig død er aktiv SLE-sykdom og infeksjoner.

\section{REFERANSER}

1. Gladman DD, Urowitz MB. Prognosis, mortality, and morbidity in systemic lupus erythematosus. In: Wallacc DJ, Hahn BH, eds. Dubois' Lupus Erythematosus. Philadelphia: Lippincott, 2002: 1255-1273.

2. Gilboe IM, Kvien TK, Husby G. Disease course in systemic lupus erythematosus: Changes in health status, disease activity and organ damage after 2 years. J Rheumatol 2001; 28: 266-274.

3. Stoll T, Sutcliffe N, Mach J, Klaghofer R, Isenberg DA. Analysis of the relationslip between disease activity and damage in patients with systemic lupus erythematosus - a 5-yr prospective study. Rheumatology 2004; 43: 1039-1044.

4. Cohen AS, Reynolds WE, Franklin EC et al. Preliminary criteria for the classification of systemic lupus erythematosus. Bull Rheum Dis 1971; 21: 643-648.

5. Tan EM, Cohen AS, Fries JF et al. The 1982 revised classification criteria of systemic lupus erythematosus. Arthritis Rheum 1982; 25: 1271-1277.

6. Hochberg MC. Updating for the American College of Rheumatology of Rheumatology for the revised classification criteria of systemic lupus erythematosus. Arthritis Rheum 1997; 40: 1725.

7. Levin RE, Weinstein A, Peterson M, Testa MA, Rothfield NF. A comparison of the sensitivity of the 1971 and 1982 American Rheumatism Association criteria for the classification of systemic lupus erythematosus. Arthritis Rheum 1984: 27: 530-538. 
8. Gilboe IM, Husby G. Application of the 1982 revised criteria for the classification of systemic lupus erythematosus on a cohort of 346 Norwegian patients with connective tissue disease. Scand J Rheumatol 1999; 28: 81-87.

9. Nived O, Sturfelt G, Wollheim F. Systemic lupus erythematosus in an adult population in southern Sweden: Incidence, prevalence and validity of ARA revised classification criteria. Br J Rheumatol 1985; 24: 147-154.

10. Stahl-Hallengren C, Jonsen A, Nived O, Sturfelt G. Incidence studies of systemic lupus erythematosus in Southern Sweden: increasing age, decreasing frequency of renal manifestations and good prognosis. $J$ Rheumatol 2000; 27: 685-691.

11. Nossent HC. Systemic lupus erythematosus in the Arctic region of Norway. J Rheumatol 2001; 28: 539-546.

12. Jonsson H, Nived O, Sturfelt G. Outcome in systemic lupus erythematosus: a prospective study of patients from a defined population. Medicine 1989; 68: 141-150.

13. Voss A, Green A, Junker P. Systemic lupus erythematosus in Denmark: Clinical and epidemiological characterization of a county-based cohort. Scand J Rheumatol 1998; 27: 98-105.

14. Helve T. Prevalence and mortality rates of Systemic lupus erythematosus and causes of death in SLE patients in Finland. Scand J Rheumatol 1985; 14: 43-46.

15. Gudmundsson S, Steinsson K. Systemic lupus erythematosus in Iceland 1975 through 1984. A Nationwide epidemiological study in an unselected population. J Rheumatol 1990; 17: 1162-1167.

16. Petri M. Epidemiology of systemic lupus erythematosus. Clin Rheum 2002; 16: 847-858.

17. Uramoto KM, Michet CR Jr, Thumboo et al. Trends in the incidence of systemic lupus erythematosus, 19501992. Arthritis Rheum 1999; 42: 46-50.

18. Petri M, Perez-Gutthann S, Longenecker JC et al. Morbidity of systemic lupus erythematosus: role of race and socioeconomic status. Am J Med 1991; 91: 345-353.

19. Alarcon G, McGwin GJ, Bastian H et al. Systemic lupus erythematosus in three ethnic groups. VIII. Predictors of early mortality in the Lumina cohort. Arthritis Care Res 2001; 45: 101-202.

20. Abu-Shakra M, Urovitz MB, Gladman DD et al. Mortality studies in systemic lupus erythematosus. Results from a single senter. II. Predictors of variables for mortality. J Rheumatol 1995; 22: 1265-1270.

21. Abu-Shakra M, Urovitz MB, Gladman DD et al. Mortality studies in systemic lupus erythematosus. Results from a single senter. I. Causes of death. J Rheumatol 1995; 22: 1259-1264.

22. Cervera R, Khamastha M, Font J et al. Morbidity and mortality in systemic lupus erythematosus during 10year period: a comparison of early and late manifestations in a cohort of 1,000 patients. Medicine 2003; 82: 299-308.

23. Manzi S, Meilahn EN, Rairie JE et al. Age-specific incidence rates of myocardial infarction and angina in women with systemic lupus erythematosus: comparison with the Framingham Study. Am J Epidemiol 1997; 145: 408-415.

24. Esdaile JM, Abrahamowicz M, Grodzicky T et al. Traditional Framingham risk factors fail to fully account for accelerated atherosclerosis in systemic lupus erythematosus. Arthritis Rheum 2001; 44: 2331-2337.

25. Urowitz MB, Bookman AAM, Koehler BE et al. The bimodal mortality pattern of systemic lupus erythematosus. Am J Med 1976; 60: 221-225.

26. Becker-Merok A, Nossent HC. Damage accumulation in systemic lupus erythematosus and its relation to disease activity and mortality. $J$ Rheumatol 2006; 33: 1570-1577.

27. Gripenberg M, Helve T. Outcome of systemic lupus erythematosus. A study of 66 patients over 7 years with the special reference to the predictive value of anti-DNA antibody determinations. Scand J Rheumatol 1991; 20: 104-109.

28. Jacobsen S, Petersen J, Ullman S et al. Mortality and causes of death of 513 Danish patients with systemic lupus erythematosus. Scand J Rheumatol 1999; 28: 75-80.

29. Halberg P, Bendixen G, Kriegbaum NJ et al. Systemic lupus erythematosus. 1. Disease manifestations, infections, thrombotic episodes, causes of death and survivial in a case of 173 patients followed for 13.9 years. Ugeskr Laeger 1991; 153: 1700-1704.

30. Bjørnådal L, Yin L, Granath F et al. Cardiovascular disease a hazard despite improved prognosis in patients with systemic lupus erythematosus: results from a Swedish population based study 1964-1995. J Rheumatol 2004; 31: 713-719.

31. Nived O, Jønsen A, Bengtsson AA et al. High predictive value of the Systemic lupus International Collaborating Clinics/American College of Rheumatology damage index for survivial in systemic lupus erythematosus. J Rheumatol 2002; 29: 1398-1400.

32. Bernatsky S, Boivin J-F, Joseph L et al. Mortality in systemic lupus erythematosus. Arthritis Rheum 2006; 54: 2550-2557. 